\section{Parliament in Britain}

Mr. R. Maudling, in opening a debate in the House of Commons on February 23 about the proposed increase in fees for overseas students, once again questioned the magnitude of the anticipated savings of $\mathfrak{2 - 5}$ million per year. The Secretary of State for Education and Science, Mr. A. Crosland, who followed, gave figures as to the increase in the subsidy to overseas students over the last 10 years. He stated that over 95 per cent of the fees of undergraduates were paid out of local authority awards, and claimed that to increase the fees of all British university students to the point where they represented 20 per cent of recurrent costs as proposed by the Robbins Committee and the Estimates Committee would involve an addition of $£ 8$ million to the rates. There was a consensus of opinion that the number of overseas students should be maintained at least at its present level, and in winding up for the Government, Mr. G. Roberts could only add that what had been said would be carefully considered and that the total grant to universities could assume an increase of $£ 250$ per annum per overseas student.

IN reply to questions in the House of Commons later in the week, Mr. A. Crosland gave an analysis of the geographical origin of the 16,256 full-time overseas students at British universities in 1965-66: 1,873 were from Western Europe, 9,081 from the Commonwealth, 1,643 from the United States and 3,659 from other countries. Of those from Commonwealth countries, 1,289 were estimated as from advanced and 7,792 from developing countries. Of the $16,256,2,189$ were supported by United Kingdom public funds; 970 from other United Kingdom funds, including University awards; 2,415 by the Governments of developing countries; 1,906 by other overseas governments and services; and 8,776 were privately financed. In all 10,890 came from developing countries and 5,416 were privately financed. No figures are available of overseas students who hold no awards but 4,855 from Commonwealth countrics were privately financed.

IN a written answer in the House of Commons on February 13, the Minister of State, Mr. G. Roberts, gave the expenditure of the Medical Research Council in 1963-64, excluding capital expenditure, specifically on cancer research as $£ 958,000$, of which $£ 531,000$ was on the Council's units and external staff, $f 373,000$ on grants to university research workers and $f 54,000$ on grants to other research workers; for 1964-65 the corresponding figures were $£ 1,029,000, £ 548,000, £ 415,000$ and $£ 66,000$; for $1965-66$, £1,178,000, $£ 643,000$, $£ 461,000$ and $£ 74,000$; and for $1966-67, £ 1,270,000$, $£ 696,000$, $£ 484,000$ and $£ 90,000$. No estimate could be given of the proportion of Government funds applied to this purpose from grants given on the advice of the University Grants Committee to universities and medical schools or of the amount spent by hospitals within the National Health Service.

Baroness PHullips, answering a question in the House of Lords, said that in 1965-66 there were 2,471 undergraduate students of agriculture and 562 postgraduates in British universities. Rationalizing the teaching of agriculture in Britain was the responsibility of the U.G.C., she added.
University News:

Aston in Birmingham

Dr. E. Braun, at present head of the Department of Physics in the West Ham College of Technology, has been appointed professor of physics as from September 1 .

Birmingham

THE personal title of professor of comparative endocrinology has been conferred on Sir Francis Knowles, reader in comparative endocrinology at the university.

Cambridge

Dr. P. W. Anderson of the Bell Telephone Laboratories will be visiting professor in theoretical physics at the Cavendish Laboratory in the University of Cambridge from October 1967. During his stay in Cambridge he will teach only two terms out of threo each year so that he can maintain his relationship with the Bell Telephone Laboratories. Dr. Anderson works principally in solid state physics.

Edinburgh

Dr. Charlotte Auerbacir, at present reader in the Department of Animal Genetics, has been appointed to a personal chair in genetics, with effect from October 1.

Manchester Institute of Science and Technology

Dr. L. R. G. Treloar, at present reader in the Department of Polymer and Fibre Science, has been appointed to a newly established chair of polymer and fibre science.

Nottingham

Dr. J. S. L. LEACH, at present reader in physical metallurgy in the Imperial College of Science and Technology, has been appointed to the Cripps chair of metallurgy, and to the headship of the department.

\section{Announcements}

THe Council of the Institute of Physics and the Physical Society has made the following awards for 1967: Guthrie Medal and Prize to Sir James Chadwick, formerly Lyon Jones professor of physics in the University of Liverpool and Master of Gonville and Caius College, Cambridge; Glazebrook Medal and Prize to Sir Charles Sykes of Firth Brown Limited; Thomas Young Medal and Prize to Pro. fessor D. Gabor of Imperial College of Science and Technology, London; Charles Chree Medal and Prize to Dr. J. H. Chapman of the Defence Research Telecommunications Establishment, Canada; Duddell Medal and Prize to Dr. K. D. Froome and Mr. R. H. Bradsell of the National Physical Laboratory; Charles Vernon Boys Prize to Dr. A. H. Cook of the National Physical Laboratory; Bragg Medal and Prize to the late Mr. D. MeGill, at the time of his death organizer of the Physies Section of the Nuffield Foundation Science 'Teaching Project.

THE Council of the Edinburgh Geolugical Society has nominated Mr. W. Mykura, Institute of Geological Sciences, Edinburgh, for the Clough Award for 1966/67, in recognition of his geological work in tho south of Scotland.

The British Socicty of Audiology has recently been established, and the chairman of the provisional council is Dr. J. D. Hood of the Otological Research Unit, National Hospital, Queen Square, London. Tho aims of the socioty are to promote learning and advance education in the subject of audiology, to provide a common platiorm for discussion among the various disciplines involved in audiological work and to promote the status of audiology as a discipline. Further information concerning the society may be obtained from Dr. L. Fisch, Hearing Clinic, Vicarage Farm Road, Heston, Middlesex, or Mr. A. Boothroyd, Department of Audiology, University of Manchester, Manchester 13. 